\title{
Sorption and Desorption of Picloram in Soils under Pastures IN BRAZIL ${ }^{1}$
}

\author{
Sorção e Dessorção do Picloram em Solos Cultivados com Pastagens no Brasil
}

\author{
ASSIS, E.C. ${ }^{2}$, SILVA, A.A. ${ }^{3}$, BARBOSA, L.C. ${ }^{4}$, QUEIROZ, M.E.L.R. ${ }^{4}$, D’ANTONINO, L. ${ }^{5}$ and \\ CRUZ, L.S. ${ }^{6}$
}

\begin{abstract}
The objective of this work was to determine the coefficients of sorption and desorption of picloram in Ultisol (PVA) and Oxisol (LVA), displaying different physical and chemical characteristics. Samples of soil were collected at the $020 \mathrm{~cm}$ depth in degraded pasture areas in Viçosa-MG. Firstly, the equilibrium time between the herbicide in solution and the herbicide which was sorbed in the soil was determined by the Batch Equilibrium method. The time required was 24 hours. Sorption and desorption studies were carried out under controlled laboratory conditions; the sorption evaluation consisted in adding $10.0 \mathrm{~mL}$ of herbicide solutions at different concentrations to tubes containing $2.00 \mathrm{~g}$ of soil, with vertical rotary agitation being maintained during the pre-determined equilibrium time. After centrifugation, supernatant extract cleaning and filtration, herbicide concentration was determined by high performance liquid chromatography (HPLC) with UV detection at $254 \mathrm{~nm}$. Desorption was evaluated using the samples in the tubes after the sorption tests. The Freundlich model was used for interpretation of the sorption process. Ultisol showed higher adsorption coefficient $\left(\mathrm{Kf}_{\mathrm{a}}\right)$ compared with Oxisol, which may be attributed to the lower $\mathrm{pH}$ of the soil and its higher organic matter content. Desorption process occurred in both soils; the LVA allowed greater release of the previously sorbed molecules.
\end{abstract}

Keywords: herbicide, batch equilibrium, Freundlich isotherms, HPLC.

RESUMO - Objetivou-se com este trabalho determinar os coeficientes de sorção e dessorção do picloram em Argissolo Vermelho-Amarelo (PVA) e Latossolo Vermelho-Amarelo (LVA) com diferentes características fisico-quimicas. As amostras desses solos foram coletadas na profundidade de $O$ $20 \mathrm{~cm}$ em áreas de pastagens degradadas, na região de Viçosa, MG. Primeiramente, determinou-se o tempo de equilíbrio entre o herbicida em solução e aquele que ficou sorvido no solo, por meio do método "Batch Equilibrium". O tempo necessário foi 24 h. Os estudos de sorção e dessorção foram realizados sob condições laboratoriais controladas; a avaliação da sorção consistiu em adicionar 10,0 mL de solução do herbicida com diferentes concentrações em tubos contendo 2, $00 \mathrm{~g}$ de solo, permanecendo sob agitação rotatória vertical pelo tempo de equilíbrio predeterminado. Após centrifugação, limpeza do extrato sobrenadante e filtração, a concentração do herbicida foi determinada por cromatografia líquida de alta eficiência (CLAE), com detector UV a $254 \mathrm{~nm}$. A dessorção foi avaliada utilizando as amostras contidas nos tubos, após os ensaios de sorção. O modelo de Freundlich foi utilizado para a interpretação do processo sortivo. O Argissolo Vermelho-Amarelo apresentou maior coeficiente de sorção $\left(K f_{a}\right)$ quando comparado com o Latossolo Vermelho-Amarelo, o que pode ser atribuído ao menor pH deste solo e ao seu maiorteor de matéria orgânica. O processo de dessorção ocorreu em ambos os solos; o LVA permitiu maior liberação das moléculas anteriormente sorvidas.

Palavras-chave: herbicida, batch equilibrium, isotermas de Freundlich, CLAE.

Recebido para publicação em 10.2.2011 e aprovado em 2.5.2011

2 Licenciado em Química, M.Sc., <emanuelagroufv@hotmail.com>; ${ }^{3}$ D.Sc., Professor Associado, Dep. de Fitotecnia, Universidade Federal de Viçosa - DFT/UFV; ${ }^{4}$ D.Sc., Professor Associado, do Dep. de Química - DEQ/UFV; ${ }^{5}$ Engo-Agro ${ }^{-}$, D.Sc., DFT/UFV; ${ }^{6}$ D.Sc., Professor Ensino Superior - UTFPR - Campus Mediameira. 


\section{INTRODUCTION}

Brazilian livestock is characterized by extensive exploitation of pastures. Brazil has the largest commercial herd of cattle in the world, about 202 million head; $88 \%$ of beef produced in the country originates on the flocks maintained exclusively in pastures. (IBGE -Brazilian Institute of Geography and Statistics, 2009).

Like any other culture the pastures need to be managed in a way that enables achieving sustainability from agronomic, economic and environmental points of view. However low productivity and returns of the pastures, especially in the 'cerrado' region, can be explained by poor enterprises management, inadequate management of the soil-plantanimal fodder (Pires et al., 2006) and also by the poor care about the soil fertility (Pires et al., 2006). These associated factors cause degradation of pastures and consequent weed infestation.

Among the diverse methods of weed control, chemical control has undoubtedly been the most widely used. One of the most widely used active principles of the indicated formulations to the weed control is picloram selective herbicide for grass that belongs to the group of mimetic herbicides of auxin (Santos et al., 2006; Silva \& Silva, 2007).

Picloram has $430 \mathrm{mg} / \mathrm{L}$ solubility in water and 2,3 pKa (Rodrigues \& Almeida, 2005). It presents increasing sorption according to the decrease of $\mathrm{pH}$ and increase of organic matter, and is highly leachable (Farmer \& Aochi, 1974; EPA, 1995). It can be degraded by microbial action and photodecomposition (Teixeira \& Canela, 2007), $\mathrm{CO}_{2}$ being its main product of degradation It presents an average half-life of 90 days on the field, ranging between 20 and 300 days, and depends on climatic and microbiological conditions (Rodrigues \& Almeida, 2005). However, according to EPA (1995), in soils with aerobic activity picloram presents half-life ranging between 167 and 153 days. On the other hand, in anaerobic soils it is slightly degraded and maintains about $90 \%$ of the original concentration one year after the application. Thus it is one of the most persistent herbicides of its group as it can be found in soils for more than two years after its application (Dowler et al., 1968).

As it is a weak-acid herbicide of anionic character in $\mathrm{pH}$ values in the majority of soils and environmental waters, picloram is slightly sorbed by the soil particles and presents high mobility (EPA, 1995). Its sorption is weakly related to the clay content of the soil and more significantly to the organic matter content (Farmer, 1974). Picloram has also been shown to be preferentially absorbed in its cationic or dipolar form and to grow with a decreasing $\mathrm{pH}$ (Cheung \& Biggar, 1974; Celis et al., 2002).

In contact with soil various types of interaction can occur between the herbicides and the organophilic colloids complex. Different factors collaborate for a bigger or smaller sorption of these molecules in the soil matrix, among which there are those linked to the physic-chemical characteristics, such as Octanol-Water Partition Coefficient (Kow), the electrolytic dissociation capacity $(\mathrm{pKa})$, the acid-base character, the molecular weight and the solubility, together with soil characteristics as organic matter, texture and mineralogy and pH (Silva \& Silva, 2007).

The degradation processes, movement through soil and also the absorption by the plants and its efficiency in the weeds control, especially the ones of the herbicides used in pre-emergence, are directly connected to the processes of sorption and desorption that these molecules can undergo in the soil (Oliveira et al., 2005). Other factors connected to the soils such as ionic strength, cation exchange capacity (CTC) and thickness of diffuse double layer can also influence the processes of sorption and desorption of herbicides (Farmer \& Aochi, 1974).

The desorption means liberation of the previously sorbed herbicide molecule back to the solution of the soil and its intensity reflects the reversibility of the sorptive process. The permanence of the sorbed herbicide causes the phenomenon called hysteresis (H). High index of hysteresis indicates greater difficulty of the herbicide to return to the soil solution which enables its greater persistence in this matrix (Silva \& Silva, 2007). 
Although there are studies related to the picloram behavior in soils (McCall et al., 1972; Biggar \& Cheung, 1973; Farmer \& Aochi, 1974; Hang et al., 1996; Lu et al., 2002; Celis et al., 2002), these were realized in soils of temperate climate. Studies on behavior and distribution of this herbicide in soils of tropical regions as Brazil are yet scarce.

Considering that the soils consist of materials of different origins, forming a clayorganic complex with changing physicchemical characteristics that interact with herbicides, there is still a need for studies to be realized so that this xenobiotic is safely recommended maintaining its efficiency in the weeds control and reducing the risk of environmental contamination. Thus this work has the objective to determine the coefficients of sorption and desorption of picloram in a Oxisol and Ultisol largely used with pastures in Brazil.

\section{MATERIAL AND METHODS}

Samples of Ultisol (PVA) and Oxisol (LVA) were collected on the depth of 0 to $20 \mathrm{~cm}$, in degraded herbicides- free pastures areas in the region of Viçosa, MG. These samples were sieved in meshes of $4 \mathrm{~mm}$ and stored in polyethylene boxes of $1 \mathrm{~m}^{3}$ of capacity. To realize the experiment samples of two soils were sieved in meshes of $2 \mathrm{~mm}$ and air dried until becoming a constant mass. The physicchemical characteristics and the textural classification of the soils are presented in the Table 1.
The stock solution of the herbicide was prepared from the standard with $98,5 \%$ of purity in the concentration of $10,0 \mathrm{mg} \mathrm{L}^{-1}$ and the working solutions prepared in $\mathrm{CaCl}_{2}$ $0,01 \mathrm{~mol} \mathrm{~L}^{-1}$ starting from diluting the stock.

The equilibration time necessary for the sorption between picloram and the soils was determined based on the batch equilibrium method (OECD, 2000). Picloram solution was prepared (purity 98,5\%) in concentration of $100 \mu \mathrm{g} \mathrm{L}^{-1}$, in solution of $\mathrm{CaCl}_{2} 0,01 \mathrm{~mol} \mathrm{~L}^{-1}$. Then $10,0 \mathrm{~mL}$ of that solution were added to polypropylene tubes with conical bottom containing 2,00 g of soil. Each tube containing soil and the herbicide solution was subjected to vertical rotary agitation during different time intervals $(1,4,8,12,16,18,20,24$ and 36 hours) in room temperature $\left(25 \pm 2{ }^{\circ} \mathrm{C}\right)$. After the agitation the samples were centrifuged at $3.500 \mathrm{rpm}$ during 10 minutes. A volume of approximately $1,5 \mathrm{~mL}$ of supernatant was filtered in Milipore membrane with $0,45 \mu \mathrm{m}$ of pore directly in vials and after that analyzed by high performance liquid chromatography (HPLC). The equilibration time was considered the one when the concentration of the supernatant solution remained constant.

In order to evaluate the sorption of picloram in the soils, herbicide solutions were prepared in $\mathrm{CaCl}_{2} 0,01 \mathrm{~mol} \mathrm{~L}^{-1}$. In the PVA soil the levels of concentration varied between 60 and $360 \mu \mathrm{g} \mathrm{L}^{-1}$, and in LVA between 60 and $300 \mu \mathrm{g} \mathrm{L}$. These levels were chosen as they can be used in determined conditions of application (Farmer \& Aochi, 1974).

Table 1 - Physic-chemical characterization and textural classification of the soil samples

\begin{tabular}{|c|c|c|c|c|c|c|c|c|c|c|}
\hline \multicolumn{11}{|c|}{ Granulometric analysis } \\
\hline Soil & \multicolumn{2}{|c|}{ Clay } & Silt & \multicolumn{2}{|c|}{ Fine sand } & Grit & \multicolumn{4}{|c|}{ Textural Classification } \\
\hline PVA & \multicolumn{2}{|l|}{26} & 16 & \multicolumn{2}{|l|}{29} & 29 & \multicolumn{4}{|c|}{ Franco Argiloarenosa } \\
\hline LVA & 35 & & 21 & 30 & & 14 & \multicolumn{4}{|c|}{ Argiloarenosa } \\
\hline \multicolumn{11}{|c|}{ Chemical Analysis } \\
\hline \multirow[t]{2}{*}{ Soil } & $\mathrm{pH}$ & $\mathrm{P}$ & $\mathrm{K}^{+}$ & $\mathrm{Ca}^{++}$ & $\mathrm{Mg}^{++}$ & $\mathrm{H}+\mathrm{Al}$ & $\begin{array}{l}\text { Total } \\
\text { CTC }\end{array}$ & $\mathrm{V}$ & $\mathrm{m}$ & MO \\
\hline & $\left(\mathrm{H}_{2} \mathrm{O}\right)$ & \multicolumn{6}{|c|}{$\left(\mathrm{cmol} \mathrm{dm}^{-2}\right)$} & \multicolumn{2}{|c|}{$(\%)$} & $\left(\right.$ dag kg $\left.{ }^{-1}\right)$ \\
\hline PVA & 4,96 & 12,1 & 61 & 3,2 & 1,6 & 4,79 & 4,96 & 51 & 0 & 3,10 \\
\hline LVA & 6,33 & 124,2 & 59 & 12,0 & 6,6 & 3,14 & 18,75 & 86 & 0 & 1,70 \\
\hline
\end{tabular}


In polypropylene tubes with conical bottom and screw cap, were placed 2,00 g of soils and $10,0 \mathrm{~mL}$ of the standard solution. Then these tubes were subjected to vertical rotary agitation at $25 \pm 2{ }^{\circ} \mathrm{C}$ during the time interval equal to the equilibrium one determined before. After agitation the samples were centrifuged at $3.500 \mathrm{rpm}$ during 10 minutes. Filtered in Milipore membrane, 5,0 mL were taken from the supernatant, with $0,45 \mu \mathrm{m}$ of pore, while around $1,5 \mathrm{~mL}$ were transferred to vials and subjected to chromatographic analysis.

In the picloram determination there was a high performance liquid chromatography apparatus used (Shimadzu SPD 20 $)$, equipped with stainless steel column (Shimadzu VP-ODS Shim-pack $150 \mathrm{~mm}$ x 4,6 mm d.i.) maintained at $26{ }^{\circ} \mathrm{C}$. The mobile phase consisted of the mixture of aqueous solution of $4 \%$ acetic acid and of acetonitrile $(85: 15, \mathrm{v} / \mathrm{v})$, eluted in isocratic mode with 1,2 $\mathrm{mL} \mathrm{min}^{-1}$ flow. The detection of pesticide was realized at $254 \mathrm{~nm}$.

The quantification was made through comparison of the areas obtained in the chromatograms for each test by the method of external calibration (external standard), and the identification by the retention time.

In the desorption test about $5,0 \mathrm{~mL}$ of $\mathrm{CaCl}_{2}$ 0,01 $\mathrm{mol} \mathrm{L}^{-1}$ herbicide-free solution was added to the same tubes in order to promote the shift in the balance and observe reversibility of the sorption process. These tubes were subjected to a new agitation during the same period of time and at the same temperature in which the sorption tests were realized. After the agitation the samples were centrifuged at $3.500 \mathrm{rpm}$, during 10 minutes. Once again $5,0 \mathrm{~mL}$ of the supernatant were removed and filtered in membrane of $0,45 \mu \mathrm{m}$ for a posterior chromatographic analysis. Then the quantity of sorbed herbicide in soil (Cs) in $\mu \mathrm{g} \mathrm{kg}^{-1}$ was calculated based on the difference between the quantity of standard solution initially added to the soil $(\mathrm{Cp})$ in $\mu \mathrm{g} \mathrm{L}^{-1}$ and the quantity found in the equilibrium solution (Ce) in $\mu \mathrm{g} \mathrm{L}^{-1}$. Based on the values of $\mathrm{Ce}$ and $\mathrm{Cs}$ Freundlich equation usage was made $\left(\mathrm{Cs}=\mathrm{K}_{\mathrm{f}}\right.$ $\mathrm{Ce}^{1 / \mathrm{n}}$ ) to obtain adsorption coefficients where $\mathrm{K}_{\mathrm{f}}$ and $1 / \mathrm{n}$ are empirical constants that represent the sorption capacity and intensity, respectively, and regression parameters characteristic for each soil-herbicide system (Farmer \& Aochi, 1974; Hang et al., 1996; Vieira, 1999; Archangelo et al., 2004). The $\mathrm{K}_{\mathrm{d}}$ coefficient was also calculated and represents the relation between the concentration of herbicide that remains sorbed in the Cs $\left(\mu \mathrm{g} \mathrm{g}^{-1}\right)$ soil and the one found in the equilibration $\mathrm{Ce}$ $\left(\mu \mathrm{g} \mathrm{mL}^{-1}\right)$ soil solution, for a specific quantity of added herbicide (Silva \& Silva, 2007). The hysteresis index $(\mathrm{H})$ was calculated using the $\mathrm{H}=\mathrm{n}_{\mathrm{a}} / \mathrm{n}_{\mathrm{d}}$ equation where $\mathrm{n}_{\mathrm{a}}$ and $\mathrm{n}_{\mathrm{d}}$ are curvatures presented in sorption and desorption graphics respectively. All the tests were realized in triplicate.

\section{RESULTS AND DISCUSSION}

Initially the equilibrium time between the herbicide concentration in solution and its concentration sorbed in soil was determined. The time necessary to achieve the equilibrium in PVA and LVA was observed to be 24 hours (Figure 1) and after that there was no more variation in the herbicide concentration in the supernatant solution.

The sorption isotherms linearized in picloram of the PVA and LVA soils are presented in the Figure 2. By the comparison between the isotherms and by the obtained Freundlich parameters, the $K_{\mathrm{f}}$ and $1 / \mathrm{n}$, the PVA is observed to have a greater sorption capacity than LVA. According to Giles et al. classification (1960), the Freundlich isotherms (2) presented $\mathrm{C}$ type behavior, once the $1 / \mathrm{n}$ equation parameter was higher than 1,0 in the studied soils.

Relating the sorptive capacity of the soils with their main constituents which determine the sorption of weak-acid herbicides such as $\mathrm{pH}$ and organic matter, the $\mathrm{K}_{\mathrm{f}}$ values were noticed to vary between 0,310 and 0,420 in LVA and PVA respectively. Positive relation occurred with the increase of organic material and with the decrease of $\mathrm{pH}$ in the soil. These results are similar to the ones obtained by Biggar \& Cheung (1973), Farmer \& Aochi (1974), Hang et al. (1996). However, the PVA has a superior sorption capacity than LVA and this fact is related to the quantity of the sorptive sites available to the sorption, which 


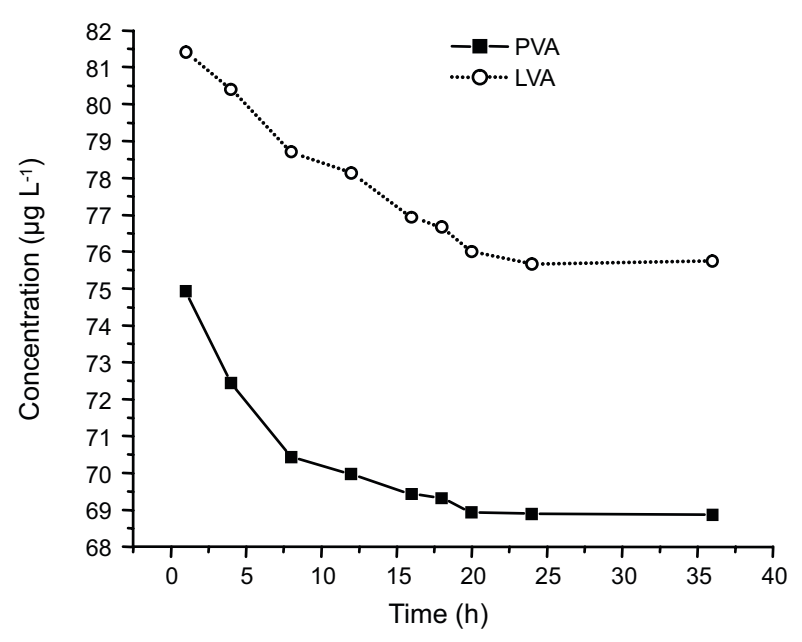

Figure 1 - Estimates of the kinetics adsorption curves for the picloram in Acrisol (PVA) and Oxisol (LVA) as a function of agitation time in hours.

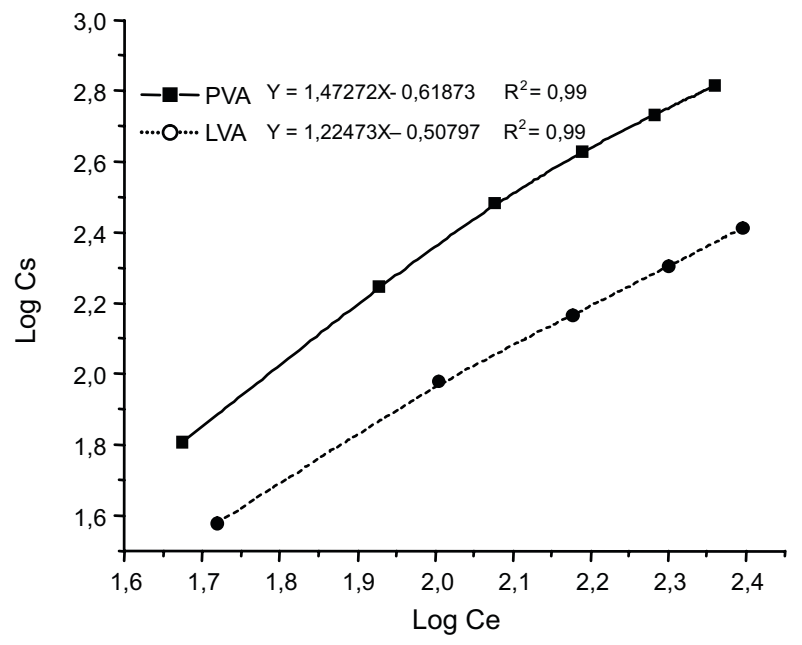

Figure 2 - Linearized sorption isotherms of picloram in Ultisol (PVA) and Oxisol (LVA)

are linked to the presence of major quantities of organic matter that has three-dimensional sites capable of acting in the retention of ionic and non-ionic compounds (Brusseau \& Rao, 1989).

The major sorption capacity of weakacid herbicides in soils with high levels of organic matter is reported by some authors (D'Antonino, 2009; Rocha et al., 2003). Although, there is a high complexity and variability of organic material present in different soils. These differences can not only interfere in the retention of the herbicides but also in its transformation and transport (Vivian et al., 2007).

It is also known that apart from organic carbon the $\mathrm{pKa}$ of the herbicide, the type and quantity of oxides present are extremely important for the sorption in highly weathered tropical soils. Silva \& Silva (2007) report that in the herbicides of acid character, the lower the soil $\mathrm{pH}$ in relation to $\mathrm{pKa}$ of the herbicide, the greater is the tendency of the herbicide to remain in the molecular (neutral) form and to be sorbed in the colloid particles of the soil.

According to Biggar \& Cheung (1973) the picloram molecule can interact with the soil colloids in different ways. These are interactions with metallic ions $\left(\mathrm{Al}^{3+}, \mathrm{Fe}^{2+}\right.$, $\mathrm{Mn}^{2+}, \mathrm{Mn}^{4+}$ ); interactions formed by metallic ions linking the picloram to the clay surface or organic matter; sorption of the protonated and dipolar forms since the displacement of protons linked to the surfaces and occupation of its sorptive sites; connections of hydrogen; Van der Waals interactions; and electrostatic interactions.

According to Cheung \& Biggar (1974), the solubility of picloram and its molecular structure in different $\mathrm{pH}$ values were evaluated and this herbicide was found to be always in ionized forms. In low $\mathrm{pH}$ values picloram is found preferentially in the cationic or dipolar forms and in higher $\mathrm{pH}$ values it is found preferentially in the anionic form. Its anionic character predominates in the natural conditions of the soils for agricultural use ( $\mathrm{pH}$ from 5,0 to 9,0); taking into consideration the presence of negative charges of the soil colloids. This preoccupies as due to being less sorbed in the soils it has more chances to be leached and thus contaminate groundwater.

The $\mathrm{pH}$ dependence of the soil and the reversibility of the sorption process indicate that the sorption of picloram is generally a surface phenomenon and does not necessarily involve specific sorption sites (Cheng, 1971). Another study that evaluated the sorption of picloram in soils with different temperatures also proved that the sorption of this herbicide 
above $36{ }^{\circ} \mathrm{C}$ is unlikely or doesn't happen due to the increase of internal molecular energy. This increase of energy reduces the interactions between the herbicide molecules and the sorptive surface along with increasing its solubility in water (Hang et al., 1996).

The linearized isotherms of desorption of PVA and LVA are presented in the Figure 3. The Freundlich constants obtained in the $\mathrm{K}_{\mathrm{fa}}$ $1 / \mathrm{n}_{\mathrm{a}}, \mathrm{K}_{\mathrm{fd}}, 1 / \mathrm{n}_{\mathrm{d}}$ sorption-desorption tests, as well as the $K_{d}$ distribution coefficient of the studied soils can be found in the Table 2. The Freundlich $\mathrm{K}_{\mathrm{fa}}$ constants of the soils followed the tendency of its $\mathrm{K}_{d}$ distribution coefficients, that is the soil with a higher sorption capacity also presented a higher distribution coefficient. The determination coefficients obtained $\left(\mathrm{R}^{2}\right)$ indicate a good compliance with the Freundlich relation.

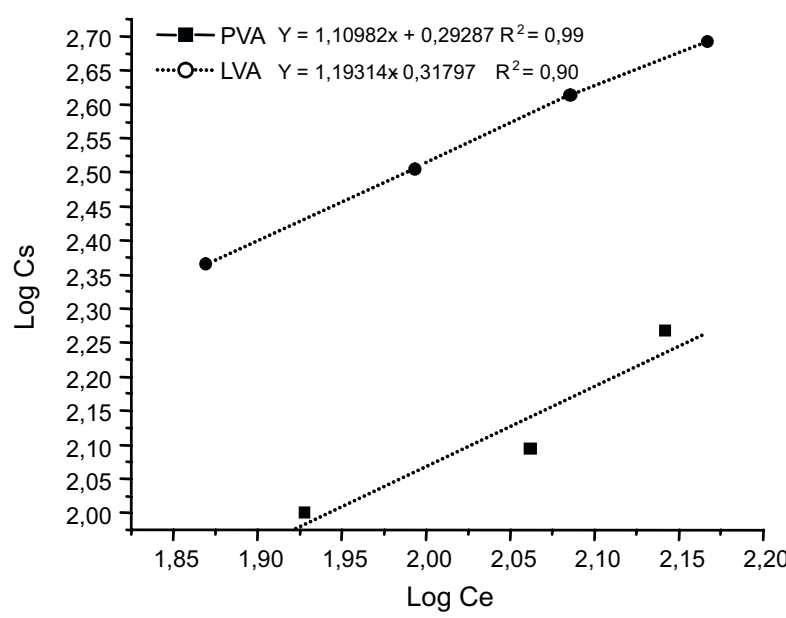

Figure 3 - Estimate of the linearized desorption isotherms of picloram in Ultisol (PVA) and Oxisol (LVA).
As far as desorption parameters are concerned, all the $K_{\mathrm{fd}}$ desorption coefficients were observed to be higher than the $\mathrm{K}_{\mathrm{fa}}$ sorption ones, while the opposite was observed in the $1 / \mathrm{n}$ parameter where the values estimated in the desorption $\left(1 / n_{d}\right)$ were lower than the sorption ones $\left(1 / \mathrm{n}_{\mathrm{a}}\right)$. The desorption process intensity was related to the low $\mathrm{pH}$ of the soil and to the increase of the organic matter content. This means that the desorptive process is lower in soils with a higher level of organic material and less $\mathrm{pH}$ values (Farmer et al., 1974; Hang et al., 1996).

The PVA was also verified to present higher $\mathrm{Kf}_{\mathrm{d}}$ and $1 / \mathrm{n}_{\mathrm{d}}$ values meaning that these soils presented major difficulty in releasing the herbicide back to the soil solution. This fact is also evident in the expressive difference between $\mathrm{Kf}_{\mathrm{a}}$ and $\mathrm{Kf}_{\mathrm{d}}$. In LVA, the difference between the $\mathrm{Kf}_{\mathrm{a}}$ and $\mathrm{Kf}_{\mathrm{d}}$ is small, which indicates that the big part of the herbicide sorbed before returned to the soil solution, maintaining the equilibrium conditions close to the initial conditions of the sorption experiment. The hysteresis index $(\mathrm{H})$ obtained in the PVA was also higher than the one obtained in the LVA, indicating its greater capacity of herbicide retention.

The sorption process of picloram herbicide was greater in the PVA than in the LVA. It is possible to affirm that it occurred due to the higher level of organic matter and lower $\mathrm{pH}$ level of the PVA. It is known that the desorption process was also influenced by the organic material and by the $\mathrm{pH}$ level of its soils'. The picloram was desorbed in both soils; the LVA allowed greater release of these molecules. The hysteresis index of picloram was higher in the PVA than in the LVA, indicating a bigger capacity of herbicide retention by the PVA.

Table 2 - Experimental value found for $\mathrm{K}_{\mathrm{d}}$ and estimate values of the adsorption $\left(\mathrm{Kf}_{\mathrm{a}}\right.$ and $\left.1 / \mathrm{n}_{\mathrm{a}}\right)$ and desorption $\left(\mathrm{Kf}_{\mathrm{d}}\right.$ e $\left.1 / \mathrm{n}_{\mathrm{d}}\right)$ coefficients based on Freundlich equation and hysteresis index $(\mathrm{H})$ of picloram in Oxisol (LVA) and Acrisol (PVA)

\begin{tabular}{|c|c|c|c|c|c|c|c|c|}
\hline \multirow{2}{*}{ Soil type } & \multicolumn{4}{|c|}{ Sorption } & \multicolumn{3}{c|}{ Desorption } & \multicolumn{1}{c|}{$\begin{array}{c}\mathrm{K} \\
{\left[\left(1 / \mathrm{n}_{\mathrm{a}}\right) /\left(1 / \mathrm{n}_{\mathrm{d}}\right)\right]}\end{array}$} \\
\cline { 2 - 9 } & $\mathrm{K}_{\mathrm{d}}$ & $\mathrm{Kf}_{\mathrm{a}}$ & $1 / \mathrm{n}_{\mathrm{a}}$ & $\mathrm{R}^{2}$ & $\mathrm{Kf}_{\mathrm{d}}$ & $1 / \mathrm{n}_{\mathrm{d}}$ & $\mathrm{R}^{2}$ & 1,327 \\
\hline $\begin{array}{c}\text { PVA } \\
\text { pH 4.96 }\end{array}$ & 2,400 & 0,420 & 1,472 & 0,99 & 1,962 & 1,109 & 0,99 & 1,025 \\
\hline $\begin{array}{c}\text { LVA } \\
\text { pH 6.33 }\end{array}$ & 0,924 & 0,310 & 1,224 & 0,99 & 0,480 & 1,193 & 0,90 & 1,03 \\
\hline
\end{tabular}




\section{LITERATURE CITED}

ARCHANGELO, E. R. et al. Sorção, dessorção e potencial de lixiviação de dimethenamid em solos brasileiros.

Planta Daninha, v. 22, n. 3, p. 467-477, 2004.

BIGGAR, J. W., CHEUNG, M. W. Adsorption of picloram (4-amino-3,5,6-trichloropicolinic acid) on Paloche, Ephrata, and Palouse soils: a thermodynamic approach to the adsorption mechanism. Soil Sci. Soc. Am. Proc., v. 37, p. 863-868, 1973.

BRUSSEAU, M. L.; RAO, P. S. C. The influence of sorbateorganic matter interactions on sorption nonequilibrium.

Chemosphere, v. 18 n. 9/10, p. 1691-1706, 1989.

CELIS, R. et al. Clay-herbicide complexes to retard picloram leaching in soil. Inter. J. Environ. Anal. Chem., v. 82, n. 8-9, p. 503-517, 2002.

CHENG, H. H. Picloram in soil: extraction and mechanism of adsorption. B. Environ. Contam. Toxicol., v. 6, n. 1, p. $28-33,1971$

CHEUNG, M. W.; BIGGAR, J. W. Solubility and molecular structure of 4-amino-3,5,6-trichloropicolinic acid in relation to pH and temperature. J. Agric. Food Chem., v. 22, n. 2, p. 202-206, 1974.

D'ANTONINO, L. et al. Lixiviação do picloram em Argissolo-Vermelho Amarelo e Latossolo Vermelho-Amarelo com diferentes valores de pH. Planta Daninha, v. 27, n. 3, p. 589-600, 2009.

DOWLER, C. C. et al. Effect and persistence of herbicides applied to soil in Puerto Rican forests. Weed Sci., v. 16. p. $45-50,1968$.

ENVIRONMENTAL PROTECTION AGENCY - EPA Reregistration Eligibility Decision (RED): Picloram. Prevention, pesticides, and toxic substances, 1995. (EPA 738-R95-019)

FARMER, W. J.; AOCHI, Y. Picloram sorption by soils. Soil Sci. Soc. Am. Proc., v. 38. p. 418-423, 1974.

GLES, C. H. et al. Studies in adsorption: part XI. A system of classification of solution adsorption isotherms, and its use in diagnosis of adsorption mechanism and in measurement of specific surface areas of solids. J. Chem. Soc., v. 111. p. $3973-3993,1960$

HANG, S. B. et al. Picloram adsorption-desorption by soils and other pure adsorbents. Eur. Soil Sci., v. 29, n. 7, p. 775-782, 1996.
INSTITUTO BRASILEIRO DE GEOGRAFIA E

ESTATÍSTICA - IBGE. Disponível em: http://

www.ibge.gov.br/home/presidencia/noticias/

noticia_visualiza.php?id_noticia $=1499 \&$ id_pagina $=1$. Acesso em: 22 nov. 2009.

LU, J. et al. Anionic polyacrylamide effects on soil sorption and desorption of metolachlor, atrazine, 2,4-D, and picloram. J. Environ. Qual., v. 31, p. 1226-1233, 2002

McCALL, H. G. et al. Adsorption and desorption of picloram, trifluralin, and paraquat by ionic and nonionic exchange resins. Weed Sci., v. 20, n. 3, p. 250-255, 1972 .

ORGANIZATION FOR ECONOMIC CO-OPERATION AND DEVELOPMENT - OECD. OECD guidelines for testing of chemicals, adsorption, 106. Paris: 2000.

OLIVEIRA, M. F. et al. Sorção e hidrólise do herbicida Flazasulfuron. Planta Daninha, v. 23, n. 1, p. 101-113, 2005.

PIRES, W. et al. Manual de pastagem: formação, manejo e recuperação. Viçosa, MG: Aprenda Fácil, 2006. 302 p.

ROCHA, W. S. D. et al. Energia livre da sorção de imazaquin em solos ácricos. R. Bras. Ci. Solo, v. 27, n. 2, p. 239-246, 2003.

RODRIGUES, B. N.; ALMEIDA, F. S. Guia de herbicidas. 5.ed. Londrina: Grafmarke, 2005.

SANTOS, M. V. et al. Eficácia e persistência no solo de herbicidas utilizados em pastagens. Planta Daninha, v. 24, n. 2, p. 391-398, 2006.

SILVA, A. A.; SILVA, J. F. (Eds.). Tópicos em manejo de plantas daninhas. Viçosa, MG: Universidade Federal de Viçosa, 2007. 367 p.

TEIXEIRA, S. C. G.; CANELA, M. C. Degradação do pesticida Padron ${ }^{\circledR}$ por processos fotoquímicos utilizando luz artificial e solar. Química Nova, v. 30, n.8, p. 1830-1834, 2007.

VIEIRA, E. M. et al. Estudo da adsorção/dessorção do ácido 2,4 diclorofenoxiacético (2,4-D) em solo na ausência e presença de matéria orgânica. Química Nova, v. 22, n. 3, p. 305-308, 1999.

VIVIAN, R. et al. Adsorção e dessorção de trifloxysulfuronsodium e ametryn em solos brasileiros. Planta Daninha, v. 25, n. 1, p. 97-109, 2007. 